\title{
The political economy of the European Union
}

\section{Andreas Dür ${ }^{1} \cdot$ Christoph Moser ${ }^{2,3,4,5} \cdot$ Gabriele Spilker $^{1}$}

Published online: 26 May 2020

(C) Springer Science+Business Media, LLC, part of Springer Nature 2020

The European Union (EU) currently faces many challenges. The departure of the United Kingdom in early 2020 means that for the first time in its history, it lost rather than gained a member state. Several of its member states still struggle with the long-term consequences of the financial and economic crisis that started back in 2008. The economic impact of the Covid-19 crisis is likely to further strain the economies of the EU's member states. The backlash to globalization that characterizes much of the developed world in the twenty-first century imposes limits on the EU's ability to advance its trade policy agenda. Last but not least, Euroscepticism has taken hold across many EU member states, carried by populist parties that have seen their electoral fortunes improve over the past few years.

It is against this background that this special issue advances research on the political economy of the EU. Political economy research investigates the interaction between politics and economics, that is, how political factors influence economic outcomes such as trade or economic growth and how economic outcomes affect politics. Both economists and political scientists contribute to this field of research, with the former mainly focusing on the impact of politics on economic outcomes, and the latter mainly interested in the effect of economic outcomes on politics. Economists, for example, ask: What are the economic gains from European integration and, specifically, from the EU customs union and European Monetary Union? To what extent are EU policies able to foster market efficiency and could some of these policies distort markets? What political economy mechanisms are at work at European institutions? Political scientists studying the political economy of the EU address questions such as: How has the Euro crisis affected the process of European integration? Can the EU use its extensive trade ties with third countries to reach broader foreign policy goals such as the enforcement of labor rights or environmental regulation? To what extent can the distributional effects of European integration explain Euroscepticism?

Andreas Dür

andreas.duer@sbg.ac.at

1 University of Salzburg, Salzburg, Austria

2 FAU Erlangen-Nürnberg, Nüremberg, Germany

3 LASER, Nüremberg, Germany

4 ETH Zürich, KOF, Zürich, Switzerland

5 CESifo, Munich, Germany 
Research on these questions can shed much light on the challenges that the EU currently faces. Whether Euroscepticism and the rise of populist parties are driven by the material consequences of EU policies and globalization or by perceived challenges to people's cultural identities matters for more than our understanding of current trends. It also has real-world consequences, for example for strategies that may be adopted to counteract Euroscepticism. Similarly, identifying the political causes of the Euro crisis may help avert future crises. Moreover, a better understanding of how EU policies affect economic growth and therefore might reduce inequality is not only important from a macro-economic perspective. It also has an important feedback loop at the political level in that changing material consequences, i.e. the living conditions of EU citizens, potentially affect individual attitudes vis-à-vis the EU itself. Hence, a crucial feature of all these questions is that the political and economic questions are closely intertwined.

In this introduction to the special issue on the political economy of the EU, we will first provide a brief assessment of the state of the art: What do we already know about the political economy of the EU? What are the issues that have attracted the most attention so far? This then allows us to identify some gaps in the existing literature. In turn, we offer a summary of the papers included in this special issue that shows how these papers contribute to the state of the art. We conclude with some thoughts on a future research agenda in this field of research.

\section{What do we know about the political economy of the EU?}

The interaction between economics and politics was not lost on early scholars of the EU. Already Ernst Haas (1958) expected economic integration to have profound political consequences. Following his neofunctionalist logic, steps towards economic integration in some sectors would have spillover effects for other sectors. Growing economic interdependence would lead to a shift in allegiances towards the new supranational institutions, in turn leading to ever more integration at the European level. More recently, Andrew Moravcsik (1998) also followed a political economy logic when explaining the process of European integration relying on his liberal intergovernmentalism. Liberal intergovernmentalism also sees economics as the driving force for integration: Economic actors lobby governments in line with their preferences to either further or halt integration in specific policy fields.

However, not only the broad theories of European integration rely on a political economy logic. Much research on specific policy fields, such as trade, investment, finance, and development aid, also draws on the basic idea that economics and politics are intertwined. Trade, as a policy field in which the EU has full competences, holds a particularly prominent role in studies of the political economy of the EU. Since becoming a customs union in the late 1960s, the EU has had the competence to speak for all member states on trade policy. For example, the EU has a representative at the World Trade Organization (WTO) and has negotiated almost 40 preferential trade agreements (PTAs) with countries spanning the entire globe (Dür et al. 2014). Correspondingly, the literature on the political economy of the EU on trade matters is impressive. Research investigates, among other things, the role the EU plays at the WTO (Dür and Zimmermann 2007; Poletti 2012; Poletti and De Bièvre 2014), the 
(divergent) interests of member states in EU trade policy in general and with regard to PTAs more specifically (Elsig 2010; Elsig and Dupont 2012), the role of EU institutions in trade policy (De Bièvre and Dür 2005; Meissner 2016), the role of interest groups or firms in influencing EU trade policy (Dür and De Bièvre 2007; Eckhardt 2011), the effect of EU PTAs on non-trade issues, such as human rights or the environment (Bastiaens and Postnikov 2017; McKenzie and Meissner 2017; Postnikov and Bastiaens 2014), or the design of EU trade agreements (Lechner 2016).

Another policy field that has attracted much political economy research is finance. The great recession following the economic and financial crisis beginning in 2008 not only had immense real-world repercussions but also triggered huge scholarly interest. This literature often builds on an older strand of literature on the political economy of currency unions, which intensively discussed and analyzed the formation of the European Monetary Union (EMU) in the 1990s (Hallerberg 2002; Mosley 2004; Wyplosz 2001). In particular, new research aimed at evaluating what caused the crisis (Baldwin et al. 2015; for an overview see Copelovitch et al. 2016), what kind of policies were implemented to help alleviate the crisis and the distributive consequences attached to these policies (Bernhard and Leblang 2016; Walter 2016), the role of EU institutions such as the European Central Bank during the crisis (Genovese et al. 2016), how member state preferences towards the European Monetary Union changed before and after the crisis (Wasserfallen et al. 2019), the design and support or rather rejection of the bailout packages, especially for Greece (Bechtel et al. 2014; Walter et al. 2018), and what the economic crisis meant and still means for European integration more generally (Jones et al. 2016; Schimmelfennig 2018).

Going beyond specific policy fields, political economy considerations have also shaped the literature on the drivers of individual level attitudes towards EU integration. The research carried out on this question closely resembles research dealing with individual level trade attitudes (for an overview see Nguyen and Spilker 2019). As European integration can at least partially be considered as moving towards more trade integration, numerous communalities exist between the driving forces of being proEuropean and being pro-trade (or pro-globalization) more generally. This link is made most explicitly by Colantone and Stanig (2018), who evaluate the China shock on the decision to vote for Leave in the Brexit referendum and find that British regions more exposed to Chinese import-competition were more likely to vote for Brexit.

More generally, there is a new strand of literature at the intersection between politics and economics that deals with the political and economic determinants of the Brexit vote, voting behavior and political polarization in the United States and Europe (Alabrese et al. 2019; Arnorrson and Zoega 2018; Becker et al. 2017). Related to that, several studies aim at identifying a causal effect of immigration on voting behavior and voting for extreme parties in Austria (Halla et al. 2017), Denmark (Dustmann et al. 2019), Italy (Barone et al. 2016) and several other countries (Edo et al. 2019). Globalization factors like trade and migration flows do not necessarily only increase voting for far-right parties, but might contribute to political polarization more generally (see for instance Autor et al. 2020).

While the United Kingdom officially left the EU at the end of January 2020, the future relations between the UK and the EU and, in particular, the form of a potential future EU-UK trade agreement are still unclear. Independent of the exact scenario, the political decision to leave the EU has and will have substantial economic effects. The 
two most common approaches to gauge the expected economic effects of Brexit are to rely on general equilibrium trade models (Dhingra et al. 2017; Oberhofer and Pfaffermayr 2020) or stock market reactions (Breinlich et al. 2018; Davies and Studnicka 2018). The economic consequences of the UK's exit from the European Union will be clearly negative, economically relevant and unevenly distributed, with the United Kingdom and EU members more closely integrated with the UK suffering from a larger drop in international trade flows and real income (for instance Oberhofer and Pfaffermayr 2020).

These estimations of economic losses due to economic disintegration largely mirror positive estimates of European economic integration. First indications of large economic gains from trade integration due to the European Coal and Steel Community (ECSC) in the early days of European integration helped to pave the way for the Treaties of Rome (1958) and the European Single Market establishing the famous four freedoms of free movement of goods, capital and persons as well as the freedom to establish and provide services. The economic and political economy literature is, however, by no means evenly distributed across these four freedoms. In particular, the economic effects of the free movement of goods are very well documented, indicating that the abolition of trade barriers within the EU customs union (e.g., Egger and Larch 2011; Berlingieri et al. 2018) and the elimination of exchange rate risk within the European Monetary Union (EMU) have clearly boosted trade in goods in Europe (e.g., Rose 2000; Nitsch 2002; Glick and Rose 2016; Polak 2019). In contrast, the empirical evidence on the free movement of capital (Lane 2006; Ehrmann et al. 2011; and Ehrmann and Fratzscher 2017), services (Dettmer 2015; Kern et al. 2018) and labor is rather scant (Dustmann et al. 2017; Beerli et al. 2020; Felbermayr et al. 2018).

Furthermore, there is a small but growing and promising body of political economy literature that takes a closer look at the performance and decisionmaking processes of important European institutions. For instance, literature on the political economy aspects of the European Commission investigates whether holding a top job in the Commission, e.g. the EU presidency (Aksoy 2010) or the Agricultural Commissioner (Gehring and Schneider 2018), increases the share of the general or the policy-specific EU budget for the respective country. Not only countries but also firms and former politicians could gain economically from their ties to top EU decision makers, raising questions about postemployment restrictions at European institutions. Vaubel et al. (2012) demonstrate that many Commissioners take private sector jobs after their tenure and Luechinger and Moser (2020) find that firms hiring former European Commissioners benefit from these corporate appointments. There is also empirical evidence that nationality plays a role at the European Central Bank for hirings of top management positions (Badinger and Nitsch 2014), networking activity (Badinger and Nitsch 2019) and, most importantly, monetary policy decisions (Hayo and Méon 2013; Badinger and Nitsch 2014).

Finally, to relate the question of EU institutions back to an issue discussed earlier, it is worthwhile to stress that the severe Euro crisis and its policy responses at the European and national level had long-lasting effects on the EU itself. Several papers indicate that fiscal austerity, economic insecurity and unemployment due to the Euro 
crisis increased votes for the UK Independence Party, lowered attitudes towards the EU and contributed to the fall in trust towards European institutions (Fetzer 2019; Guiso et al. 2019; Algan et al. 2017; Lechler 2019). Loosely speaking, strong negative economic effects of shocks that are unevenly distributed foster negative attitudes towards the EU. Since the current Covid-19 crisis will be accompanied by a serious economic - and potentially financial - crisis in many EU-member countries, this empirical evidence should serve as an important cautionary tale for European policy makers right now.

\section{Identifying gaps in our understanding of the political economy of the EU}

The discussion in the previous section has not only shown that research on the political economy of the EU is extensive, but also that it covers a variety of aspects. Nevertheless, some gaps remain, which we will discuss in more detail below. Furthermore, we want to use this section as an opportunity to call for more exchange or maybe even integration with the broader literature on international political economy (IPE).

In fact, several strands prominent in the general IPE literature do not obtain high attention in relation to the political economy of the EU. For example, the extensive political economy literature on development aid (for an overview see Wright and Winters 2010) or foreign direct investment (for an overview see Pandya 2016) do not have strong counterparts in the EU literature. The small body of literature on the EU's development aid (see, for example, Carbone 2007) hardly draws on political economy concepts. Literature using a political economy perspective to explain EU regulations with respect to foreign direct investments (both inward and outwards) is virtually absent.

Similarly, the literature investigating the political economy of migration in the EU is still much less developed compared to the literature on trade and finance. A few studies investigate public opinion towards migration in the EU, either from third countries (Bansak et al. 2016; Hangartner et al. 2019) or from other member countries (Vasilopoulou and Talving 2019), and there are some studies on the relationship between immigration and voting behavior (see above). By contrast, there is hardly any political economy research on the politics of migration more generally. The study by Huber and Oberdabernig (2016) on the welfare benefits received by immigrants versus natives in EU countries is a notable exception.

There is also still quite little political economy research on the EU's institutions. Each of the EU's major institutions - the Council, the European Commission, and the European Parliament - have attracted considerable scholarly attention. But many other European institutions have received less attention and few studies have attempted to link the behavior of these institutions to political economy forces. And whereas the major theories of European integration such as neofunctionalism and liberal intergovernmentalism do provide a political economy explanation for the most important aspects of the EU's institutional set-up, more concrete institutional outcomes have hardly been the focus of political economy research. 


\section{Outline of the special issue}

This special issue consists of six substantive papers that address several of the gaps just outlined. Four of them deal with the European Monetary Union and the Eurozone crisis. In a first contribution, Nils Redeker and Stefanie Walter (2020) address the question of why Germany, despite pressure from other countries, fails to rebalance its persistent current account surplus. Their response to this question is that the policies that would lead to adjustment, such as more public spending or higher minimum wages, would have strong distributional consequences within Germany. That is, some people would benefit from them, but others would lose. As a result, there is no agreement on how to achieve a balanced current account. In this situation, Germany opts for policies such as bailouts or debt haircuts, as they face least opposition. This paper thus is an example for political economy research that uses the distributional consequences of policies to explain the politics surrounding them.

In a second paper, Nikitas Konstantinidis and Yannis Karagiannis (2020) then investigate how conditionality in the accession process of becoming a member in the $\mathrm{E}(\mathrm{M}) \mathrm{U}$ affects the propensity of countries to later implement political and economic liberalization. The authors differentiate between intrinsic and extrinsic motivations for liberalization or reform. The former come from within the countries themselves and can be thought of as a cost-benefit analysis of further liberalization. The latter, however, are determined by the conditionality imposed by the organization. In the context of the EU, the Copenhagen Criteria as an entry barrier are an example of such extrinsic motivation in that the organization provides clear reform criteria that have to be met before the benefits of membership can be enjoyed. Using a formal model, Konstantinidis and Karagiannis show that extrinsic motivation, i.e. EU conditionality, can crowd out intrinsic motivations to reform. While this leads to short-term compliance, and thus membership, in the long term this crowding-out can even result in the reversal of reform progress. The accession of Greece to the EMU or of Hungary to the EU illustrate this pattern. Their conclusion that conditionality may be counter-productive in the long run seems not only relevant for the $\mathrm{E}(\mathrm{M}) \mathrm{U}$, but also for the broader literature on conditionality to which the article connects nicely (e.g. Dreher 2009; Stubbs et al. 2020; Vreeland 2006). The idea that countries need to be intrinsically motivated, i.e. to own a reform as Konstantinidis and Karagiannis would call it, to make a reform process work, seems very relevant also for the International Monetary Fund or the World Bank.

In a further contribution related to the EMU, Federica Genovese and Gerald Schneider (2020) analyze how parliaments in EU member states react to economic developments. Concretely, they explain variation across EU member states in how parliaments responded to the 2008 financial crisis. Their argument is that mainly the parliaments in EU member states that are not part of the Euro area and that face stark fiscal constraints should have increased their oversight of the EU's supranational institutions in response to the crisis. They use data on oversight mechanisms and on parliamentary debates in Germany, France, and Italy to test their argument. The paper nicely shows how an economic outcome (a financial crisis) can affect political institutions (and via political institutions probably also political outcomes). It thus directly addresses 
a gap in the literature on the political economy of the EU identified above, namely linking institutional outcomes to political economy forces.

The next paper also deals with important aspects of the Euro crisis. Aitor Erce, Giancarlo Corsetti and Timothy Uy (2020) discuss in detail how the European official sector policy response took shape, eventually leading to the foundation of the European Stability Mechanism (ESM) in the year 2012. Thereby, the authors provide interesting insights into similarities and differences in the IMF and European policy responses. Furthermore, the authors gather a unique dataset of the characteristics of the various official loans and debt structure of those European countries hardest hit by the financial crisis. One important finding of this paper is that Euro area loans allowed for longer maturities and lower rates, improving the repayment profile, debt management and market access, a benefit to be weighed against moral hazard concerns. This paper sheds light on a very relevant new European financial institution that has received little attention so far in the academic literature.

Related to that, while no longer focusing on the Eurozone crises, Zareh Asatryan and Annika Havlik (2020) focus their analysis on another key European financial institution, namely the European Investment Bank (EIB). The importance of this multilateral investment bank is often underestimated, considering its economic size and responsiveness relative to the EU budget. The authors investigate the allocation of loans across regions and sectors. They are interested in particular in the question of whether "home regions" of the Board of Directors of the EIB profit. Note that these directors do not serve at the EIB full-time. Hence, does the region where a given director works potentially receive a larger share of EIB-loans? Based on a new and rich dataset for about 500 individuals who have served on the EIB board, the empirical results are indeed consistent with such a "home-bias". Out of the two broad channels that could underlie this effect, with one of them being benign (i.e., better information), favoritism is more likely to be at work. To conclude, this fine empirical study makes an important contribution to the political economy literature on European institutions and at the same time contributes to studying the political economy of investment decisions within the EU.

Turning from the institutions of the EU to a specific policy area, Thomas Malang and Katharina Holzinger (2020) investigate what drives "differentiated integration" (DI), i.e. the fact that some EU member states implement and comply with only a subset of the EU's law, in agricultural policy. This question is not only interesting from the angle that agriculture accounts for $40 \%$ of the EU's budget and therefore is a highly relevant but often understudied policy field. But also, from the perspective that many pundits and scholars alike call for DI as a way for the EU to make further integration possible without forcing those who do not want to further commit to turn their back on the union. Given that in a union of 27 member states heterogeneity of preferences can easily create deadlock in negotiations, DI can be a solution by offering member states to cooperate at different levels of integration. In the context of agricultural policy, Malang and Holzinger argue, however, that DI in fact equals more protection because over the years the EU has tried to become less protectionist in its agricultural policy. Their results indeed suggest that the size of the agricultural sector is the most important factor in shaping demand for DI. However, this demand is mediated by the bargaining power of the respective country in that countries that are economically stronger can use this bargaining power to deliver higher levels of DI to their agricultural sector. In 
showing that relevant subnational interests are important determinants of EU-level outcomes, the study of Malang and Holzinger closes the circle nicely to the first study in this special issue by Redeker and Walter.

\section{A research agenda}

The contributions in this special issue add to broaden and deepen the state of the art in political economy research on the EU in several ways. First, two of the articles (Erce et al. 2020; Asatryan and Havlik 2020) study EU institutions that are - despite their economic importance - rarely in the focus of academic research. The fact that the ESM will play a decisive role in the current Covid-19 crisis only underscores the importance of studying this institution in more detail. Second, the study by Malang and Holzinger (2020) reminds us that the policy field of agriculture - despite its importance in relation to the EU budget - often receives too little attention in comparison to other policy areas, such as trade, investment or finance. An additional contribution of the Malang and Holzinger study, which is also an important part of the study by Redeker and Walter (2020), is to combine the analysis of bargaining power with domestic interests. This is an important addition to the more general IPE literature, which either mostly focuses on bargaining power (as a state level characteristic) or domestic interest (such as firms or industries) but rarely on the interplay of the two. Finally, the studies by Konstantinidis and Karagiannis (2020) as well as by Genovese and Schneider (2020) broaden our understanding of the Euro crisis either by tying the origins of the crisis to the accession of countries to the EMU or by evaluating the consequences of the crisis on national parliaments.

Despite these important additions to the study of the political economy of the EU, we see at least three additional steps that can help improve this state of the art. For one, and quite naturally, research on the political economy of the EU would benefit from interdisciplinary work bringing together economists and political scientists. As of now, the economics and political science strands of literature largely co-exist. The two strands do increasingly cite each other, which is a positive development. Actual research cooperation across the two disciplines in researching the EU, however, is still exceedingly rare. Such explicit cooperation, for example, would be useful if economic research allows for precise predictions about the preferences of economic actors, and political science research uses these predicted preferences to develop expectations about political outcomes.

Second, so far, we see at times a disconnect between the extensive literature on international political economy and the EU. IPE research focuses on countries such as the United States (mainly), Japan, China, or developing economies, and international organizations such as the World Bank and the International Monetary Fund, but largely ignores the EU. Only a small part of the research on the EU, in turn, explicitly draws on IPE research. Bringing these literatures together would allow us to figure out to what extent the EU is unique, and to what extent findings from research on countries or other international organizations can apply to the EU. There are only few exceptions to this, among them research contrasting the EU and the US approaches to enforcing environmental protection via PTAs (Bastiaens and Postnikov 2017) and a study on how membership in the UN Security Council matters for the EU's budget (Mikulaschek 2018). 
Finally, we think that the literature on the political economy of the EU could profit from a stronger focus on the distributional consequences of EU policies within EU member states. Traditionally, many empirical studies in this field have relied on either cross-country, cross-region, cross-industry variation or variation over time in order to identify and quantify the economic effects of European integration. Obviously, these studies are very informative about the average costs and benefits of European integration, but they usually cannot address the distributional effects within a country. Hence, we encourage new empirical studies based on firm- or individual-level data that isolate EU-policy shocks from other shocks, for instance, due to globalization more generally. Using specific EU-policy changes in conjunction with micro-level data would allow us to learn more about the distributional consequences of EU integration within EU member countries.

Political science research on the political economy of the EU could pick up these findings to better understand how expected economic gains and losses matter for political outcomes, including individual attitudes towards or lobbying behavior in the EU. This is what already happens in the field of IPE, where the findings from heterogeneous firm and worker models have found their way into research on both individual-level trade attitudes and firm-level trade lobbying. For the case of the EU, by contrast, so far only few studies have followed this approach, at least partly because the EU policy shocks are not as well understood as the more general globalization shock. A combination of economic and political science expertise could hence produce significant new insights concerning the link between the distributional effects of the EU on the one hand and individual-level attitudes and lobbying behavior on the other hand.

\section{References}

Aksoy, D. (2010). Who gets what, when, and how revisited: Voting and proposal powers in the allocation of the EU budget. European Union Politics, 11, 171-194.

Alabrese, E., Becker, S., Fetzer, T., \& Novy, D. (2019). Who voted for Brexit? Individual and regional data combined. European Journal of Political Economy, 56, 132-150.

Algan, Y., Guriev, S., Papaioannou, E., \& Passari, E. (2017). The European trust crisis and the rise of populism. Brookings Papers on Economic Activity, 48, 309-382.

Arnorrson, A., \& Zoega, G. (2018). On the causes of Brexit. European Journal of Political Economy, 55, 301-323.

Asatryan, Z., \& Havlik, A. (2020). The political economy of multilateral lending in European regions. The Review of International Organizations, 15(3).

Autor, D., Dorn, D., Hanson, G., \& Majlesi, K. (2020). Importing political polarization? The electoral consequences of rising trade exposure. American Economic Review, conditionally accepted. mimeo, MIT, Feb. 2020.

Badinger, H., \& Nitsch, V. (2014). National Representation in supranational institutions: The case of the European Central Bank. Journal of Comparative Economics, 42, 19-33.

Badinger, H., \& Nitsch, V. (2019). What do central bankers do? Evidence from the European Central Bank's executive board. CESifo Working Paper No. 7467.

Baldwin, R., Beck, T., Bénassy-Quéré, A., Blanchard, O., Corsetti, G., de Grauwe, P., . . di Mauro, B. W. (2015). Rebooting the Eurozone: Step 1-Agreeing a Crisis Narrative (CEPR Policy Insight, 85). http://cepr.org/sites/default/files/policy_insights/PolicyInsight85.pdf. Accessed 30 April 2020.

Bansak, K., Hainmueller, J., \& Hangartner, D. (2016). How economic, humanitarian, and religious concerns shape European attitudes toward asylum seekers. Science, 354(6309), 217-222.

Barone, G., D’Ignazio, A., de Blasio, G., \& Naticchioni, P. (2016). Mr. Rossi, Mr. Hu and politics. The role of immigration in shaping natives' voting behavior. Journal of Public Economics, 136, 1-13. 
Bastiaens, I., \& Postnikov, E. (2017). Greening up: The effects of environmental standards in EU and US trade agreements. Environmental Politics, 26(5), 847-869.

Bechtel, M., Hainmueller, J., \& Margalit, Y. (2014). Preferences for international redistribution: The divide over the Eurozone bailouts. American Journal of Political Science, 58(4), 835-856.

Becker, S., Fetzer, T., \& Novy, D. (2017). Who voted for Brexit? A Comprehensive District-level analysis. Economic Policy, 32, 601-650.

Beerli, A., Ruffner, J., Siegenthaler, M., \& Peri, G. (2020). The abolition of immigration restrictions and the performance of firms and workers: Evidence from Switzerland. NBER Working Paper No. 25302.

Berlingieri, G., Breinlich, H., \& Dhingra, S. (2018). The impact of trade agreements on consumer welfare Evidence from the EU common external trade policy. Journal of the European Economic Association, 16, 1881-1928.

Bernhard, W. T., \& Leblang, D. (2016). Sovereign debt, migration pressure, and government survival. Comparative Political Studies, 49(7), 907-938.

Breinlich, H., Leromain, E., Novy, D., Sampson, T., \& Usman, A. (2018). The economic effects of Brexit: Evidence from the stock market. Fiscal Studies, 39, 581-623.

Carbone, M. (2007). The European Union and international development: The politics of foreign aid. London: Routledge.

Colantone, I., \& Stanig, P. (2018). Global competition and Brexit. American Political Science Review, 112(2), 201-218.

Copelovitch, M., Frieden, J., \& Walter, S. (2016). The political economy of the euro crisis. Comparative Political Studies, 49(7), 811-840.

Davies, R., \& Studnicka, Z. (2018). The Heterogeneous Impact of Brexit: Early Indications from the FTSE. European Economic Review, 110, 1-17.

De Bièvre, D., \& Dür, A. (2005). Constituency interests and delegation in European and American trade policy. Comparative Political Studies, 38(10), 1271-1296.

Dettmer, B. (2015). Trade effects of the European Union's service directive: Contrasting ex ante estimates with empirical evidence. The World Economy, 38, 445-478.

Dhingra, S., Huang, H., Ottaviano, G., Pessoa, J. P., Sampson, T., \& Van Reenen, J. (2017). The costs and benefits of leaving the EU: Trade effects. Economic Policy, 32, 651-705.

Dreher, A. (2009). IMF conditionality: Theory and evidence. Public Choice, 141, 233-267.

Dür, A., \& De Bièvre, D. (2007). Inclusion without influence? NGOs in European trade policy. Journal of Public Policy, 27(1), 79-101.

Dür, A., \& Zimmermann, H. (2007). Introduction: The EU in international trade negotiations. JCMS: Journal of Common Market Studies, 45(4), 771-787.

Dür, A., Baccini, L., \& Elsig, M. (2014). The design of international trade agreements: Introducing a new dataset. The Review of International Organizations, 9(3), 353-375.

Dustmann, C., Schönberg, U., \& Stuhler, J. (2017). Labor supply shocks, native wages, and the adjustment of local employment. The Quarterly Journal of Economics, 132(1), 435-483.

Dustmann, C., Vasiljeva, K., \& Damm, A. (2019). Refugee migration and electoral outcome. Review of Economic Studies, 86, 2035-2091.

Eckhardt, J. (2011). Firm lobbying and EU trade policymaking: Reflections on the anti-dumping case against Chinese and Vietnamese shoes (2005-2011). Journal of World Trade, 45(5), 965-991.

Edo, A., Giesing, Y., Öztunc, J., \& Poutvaara, P. (2019). Immigration and electoral support for the far-left and the far-right. European Economic Review, 115, 99-143.

Egger, P., \& Larch, M. (2011). An assessment of the Europe agreements' effects on bilateral trade, GDP and welfare. European Economic Review, 55, 263-279.

Ehrmann, M., \& Fratzscher, M. (2017). Euro area government bonds - Fragmentation and contagion during the sovereign debt crisis. Journal of International Money and Finance, 70, 26-44.

Ehrmann, M., Fratzscher, M., Gürkaynak, R. S., \& Swanson, E. T. (2011). Convergence and anchoring of yield curves in the euro area. The Review of Economics and Statistics, 93(1), 350-364.

Elsig, M. (2010). European Union trade policy after enlargement: Larger crowds, shifting priorities and informal decision-making. Journal of European Public Policy, 17(6), 781-798.

Elsig, M., \& Dupont, C. (2012). European Union meets South Korea: Bureaucratic interests, exporter discrimination and the negotiations of trade agreements. JCMS: Journal of Common Market Studies, 50(3), 492-507.

Erce, A., Corsetti, G., \& Uy, T. (2020). Official sector lending strategies during the euro area crisis. The Review of International Organizations, 15(3).

Felbermayr, G., Gröschl, J., \& Steinwachs, T. (2018). The trade effects of border controls: Evidence from the European Schengen agreement. JCMS: Journal of Common Market Studies, 56(2), 335-351. 
Fetzer, T. (2019). Did austerity cause Brexit? American Economic Review, 109, 3849-3886.

Gehring, K., \& Schneider, S. (2018). Towards the greater good? EU commissioners' nationality and budget allocation in the European Union. American Economic Journal: Economic Policy, 10, 214-239.

Genovese, F., \& Schneider, G. (2020). Smoke with fire: Financial crises and the demand for parliamentary oversight in the European Union. The Review of International Organizations, 15(3).

Genovese, F., Schneider, G., \& Wassmann, P. (2016). The Eurotower strikes back: Crises, adjustments, and Europe's austerity protests. Comparative Political Studies, 49(7), 939-967.

Glick, R., \& Rose, A. (2016). Currency unions and trade: A post-EMU reassessment. European Economic Review, 87, 78-91.

Guiso, L., Herrera, H., Morelli, M., \& Sonno, T. (2019). Global crises and populism: The role of Eurozone institutions. Economic Policy, 34(97), 95-139.

Haas, E. B. (1958). The uniting of Europe: Political, social, and economic forces 1950-1957. London: Stevens \& Sons Limited.

Halla, M., Wagner, A. F., \& Zweimüller, J. (2017). Immigration and voting for the far right. Journal of the European Economic Association, 15(6), 1341-1385.

Hallerberg, M. (2002). Introduction: Fiscal policy in the European Union. European Union Politics, 3(2), 139-150.

Hangartner, D., Dinas, E., Marbach, M., Matakos, K., \& Xefteris, D. (2019). Does exposure to the refugee crisis make natives more hostile? American Political Science Review, 113(2), 442-455.

Hayo, B., \& Méon, P. (2013). Behind closed doors: Revealing the ECB's decision rule. Journal of International Money and Finance, 37, 135-160.

Huber, P., \& Oberdabernig, D. A. (2016). The impact of welfare benefits on natives' and immigrants' attitudes toward immigration. European Journal of Political Economy, 44, 53-78.

Jones, E., Kelemen, R. D., \& Meunier, S. (2016). Failing forward? The euro crisis and the incomplete nature of European integration. Comparative Political Studies, 49(7), 1010-1034.

Kern, M., Paetzold, J., \& Winner, H. (2018). Cutting red tape for trade in services. Working Papers in Economics, no. 2018-09, University of Salzburg.

Konstantinidis, N., \& Karagiannis, Y. (2020). Intrinsic vs. extrinsic incentives for reform: An informational mechanism of E(M) U conditionality. Review of International Organizations, 15(3).

Lane, P. (2006). The real effects of European monetary union. The Journal of Economic Perspectives, 20, 4766.

Lechler, M. (2019). Employment shocks and anti-EU sentiment. European Journal of Political Economy, 59, 266-295.

Lechner, L. (2016). The domestic battle over the design of non-trade issues in preferential trade agreements. Review of International Political Economy, 23(5), 840-871.

Luechinger, S. \& Moser, C. (2020). The European Commission and the revolving door. European Economic Review, forthcoming., 103461

Malang, T., \& Holzinger, K. (2020). Political economy of differentiated integration: The case of common agricultural policy. Review of International Organizations, 15(3).

McKenzie, L., \& Meissner, K. L. (2017). Human rights conditionality in European Union trade negotiations: The case of the EU-Singapore FTA. JCMS: Journal of Common Market Studies, 55(4), 832-849.

Meissner, K. (2016). Democratizing EU external relations: The European Parliament's informal role in SWIFT, ACTA, and TTIP. European Foreign Affairs Review, 21(2), 269-288.

Mikulaschek, C. (2018). Issue linkage across international organizations: Does European countries' temporary membership in the UN security council increase their receipts from the EU budget? The Review of International Organizations, 13(4), 491-518.

Moravcsik, A. (1998). The choice for Europe: Social purpose and state power from Messina to Maastricht. Ithaca: Cornell University Press.

Mosley, L. (2004). Government financial market relations after EMU: New currency, new constraints? European Union Politics, 5(2), 181-209.

Nguyen, Q., \& Spilker, G. (2019). The elephant in the negotiation room: PTAs through the eyes of citizens. In M. Elsig, M. Hahn, \& G. Spilker (Eds.), The Shifting Landscape of Global Trade Governance (pp. 1747). Cambridge: Cambridge University Press.

Nitsch, V. (2002). Honey, I shrunk the currency union effect on trade. The World Economy, 25, 457-474.

Oberhofer, H., \& Pfaffermayr, M. (2020). Estimating the trade and welfare effects of Brexit: A panel data structural gravity model. Canadian Journal of Economics, forthcoming.

Pandya, S. S. (2016). Political economy of foreign direct investment: Globalized production in the twenty-first century. Annual Review of Political Science, 19, 455-475.

Polak, P. (2019). The Euro's trade effect: A meta-analysis. Journal of Economic Surveys, 33, 101-124. 
Poletti, A. (2012). The European Union and multilateral trade governance: The politics of the Doha round. New York: Routledge.

Poletti, A., \& De Bièvre, D. (2014). Political mobilization, veto players, and WTO litigation: Explaining European Union responses in trade disputes. Journal of European Public Policy, 21(8), 1181-1198.

Postnikov, E., \& Bastiaens, I. (2014). Does dialogue work? The effectiveness of labor standards in EU preferential trade agreements. Journal of European Public Policy, 21(6), 923-940.

Redeker, N. \& Walter, S. (2020). We'd rather pay than change - The politics of German non-adjustment in the Eurozone crisis. Review of International Organizations, 15(3).

Rose, A. (2000). One money, One Market: The Effect of Common Currencies on Trade. Economic Policy (April), 9-45.

Schimmelfennig, F. (2018). European integration (theory) in times of crisis. A comparison of the euro and Schengen crises. Journal of European Public Policy, 25(7), 969-989.

Stubbs, T., Reinsberg, B., Kentikelenis, A., \& King, L. (2020). How to evaluate the effects of IMF conditionality. The Review of International Organizations, 15(1), 29-73.

Vasilopoulou, S., \& Talving, L. (2019). Opportunity or threat? Public attitudes towards EU freedom of movement. Journal of European Public Policy, 26(6), 805-823.

Vaubel, R., Klingen, B., \& Müller, D. (2012). There is life after the commission: An empirical analysis of private interest representation by former EU-commissioners, 1981-2009. The Review of International Organizations, 7, 59-80.

Vreeland, J. R. (2006). The International Monetary Fund: Politics of conditional lending. London: Routledge.

Walter, S. (2016). Crisis politics in Europe: Why austerity is easier to implement in some countries than in others. Comparative Political Studies, 49(7), 841-873.

Walter, S., Dinas, E., Jurado, I., \& Konstantinidis, N. (2018). Noncooperation by popular vote: Expectations, foreign intervention, and the vote in the 2015 Greek bailout referendum. International Organization, 72(4), 969-994.

Wasserfallen, F., Leuffen, D., Kudrna, Z., \& Degner, H. (2019). Analysing European Union decision-making during the Eurozone crisis with new data. European Union Politics, 20(1), 3-23.

Wright, J., \& Winters, M. (2010). The politics of effective foreign aid. Annual Review of Political Science, 13, 61-80.

Wyplosz, C. (2001). The impact of EMU on Europe and the developing countries. Oxford: Oxford University Press.

Publisher's note Springer Nature remains neutral with regard to jurisdictional claims in published maps and institutional affiliations. 